\title{
Carcinosarcoma of the Lung Associated with Neurofibromatosis Type 1: A Case Report
}

\section{Nörofibromatozis Tip 1 ile Akciğer Karsinosarkom Birlikteliği: Olgu Sunumu}

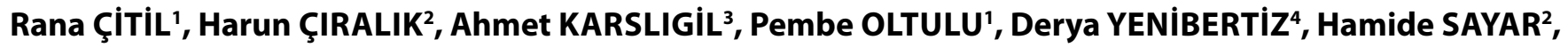 \\ Esma GÜRBÜZ²
}

Departments of ${ }^{1}$ Pathology, ${ }^{3}$ Thoracic Surgery and ${ }^{4}$ Chest Diseases, Kahramanmaraş State Hospital, KAHRAMANMARAŞ, TURKEY, ${ }^{2}$ Department of Pathology, Sütçü Imam University, Faculty of Medicine, KAHRAMANMARAŞ, TURKEY

\begin{abstract}
Neurofibromatosis or von Recklinghausen's disease is the most common inherited syndrome predisposing to neoplasia. Carcinosarcoma is a rare malignant mixed tumor of the lung. Association of carcinosarcoma of lung with Neurofibromatosis-1 is not common. A 57-year-old man presented with history of fever, cough, hemoptysis, breathlessness, weight loss, chest pain. Multiple cutaneous neurofibromas and café au lait spots were revealed by physical examination. A homogeneous opacity was found in the right middle and right upper zone on posterior-anterior chest radiography. A $8 \times 8 \times 7 \mathrm{~cm}$ mass that had irregular borders in right upper posterior and apical segment was seen on contrast enhanced chest computed tomography. On bronchoscopy, the lumen of right upper apical segment was obstructed with vegetating tumoral lesion. The biopsy taken from this region was diagnosed as carcinosarcoma by histopathological and immunohistochemical examination.A rare case with carcinosarcoma of the lung and Neurofibromatosis-1 was reported.
\end{abstract}

Key Words: Neurofibromatosis 1, Carcinosarcoma, Lung

\section{ÖZ}

Nörofibromatozis veya von Recklinghausen hastalığı neoplazilere yatkınlık oluşturan en sık genetik sendromdur. Karsinosarkom akciğerin nadir görülen malign mikst tümörüdür. Akciğerin karsinosarkomu ile nörofibromatozis 1 birlikteliği sık değildir. 57 yaşındaki erkek hasta ateş, öksürük, hemoptizi, nefes darlığı, kilo kaybı ve göğüs ağrısı şikayeti ile başvurdu. Fizik muayenede çok sayıda nörofibromlar ve café au lait lekeleri saptandı. PA akciğer filminde sağ orta ve üst zonda homojen opasite tespit edildi. Kontrastlı akciğer bilgisayarlı tomografide sağ üst posterior ve apikal segmentte $8 \times 8 \times 7$ $\mathrm{cm}$ boyutunda düzensiz sınırlı kitle görüldü. Bronkoskopide sağ üst apikal segment vejetan tümoral lezyon ile tıkalı idi. Bu bölgeden alınan biyopsi yapılan histopatolojik ve immünohistokimyasal incelemeler sonucunda karsinosarkom olarak değerlendirildi. Bu makalede nörofibromatozis 1 ve akciğerde karsinosarkom olan nadir bir olgu sunuldu.

Anahtar Sözcükler: Nörofibromatozis 1, Akciğer, Karsinosarkom

\section{INTRODUCTION}

Von Recklinghausen's disease is an autosomal dominant hereditary disease associated with characteristic cafe au lait spots of the skin and multiple neurofibromatosis. Clinical and genetic studies have demonstrated the existence of two distinct genetic forms of neurofibromatosis. The classical or peripheral form of the disease, also known as neurofibromatosis type-1 (NF-I), accounts for $85 \%$ of all cases (1). Patients with NF1 are predisposed to development of various types of malignancies. There might be also an increased risk for the development of primary lung carcinoma (2). However, the incidence of lung carcinoma occurring as a complication of NF-1 is rare.

Received : 24.09 .2010

Accepted : 18.10.2010
Recently, lung malignancies reported in association with neurofibromatosis have been reported infrequently (3-7). Carcinosarcoma of the lung is a rare tumor, constitutes approximately $0.2-0.27 \%$ of all lung cancers, and has a poor clinical outcome (8). The tumor may be located in several organs such as the esophagus, salivary glands, thymus, thyroid glands, breast, stomach, urogenital system as well as in the lungs $(9,10)$.We specifically presented this case because of the rare association of neurofibromatosis and carcinosarcoma of the lung.

\section{CASE REPORT}

A 57-year-old man applied with history of fever for 2 months and cough, hemoptysis, breathlessness, weight loss,

Correspondence: Rana ÇíTí

Department of Pathology, Kahramanmaraş State Hospital,

KAHRAMANMARASS, TURKEY

E-mail: ranacitil@gmail.com Phone: +90 3442235330 
chest pain for 1 month. He was a life-time nonsmoker, and he had been diagnosed previously as neurofibromatosis. Multiple cutaneous neurofibromas and café-au-lait spots were revealed by physical examination. In bronchoscopic examination, the lumen of the right upper apical segment was obstructed by a vegetan tumoral lesion. It was determined homogeneous opacity in the right middle and right upper zone on posterior-anterior chest radiography (Figure 1). On admission, a $8 \times 8 \times 7 \mathrm{~cm}$ mass that have irregular border in right upper posterior and apical segment was seen on contrast enhanced chest computed tomography. There was necrosis and multicystic areas within the mass. Minimal pleural effusion was also noted (Figure 2).

Grossly, the skin specimen was ovoid, ten-white mass, measuring $1 \times 1 \times 0.7 \mathrm{~cm}$. The cut surface was solid and white-gray. Histologically, the tumor contained interlacing bundles of elongated cells with wavy, darkly stained nuclei in the subcutis. The cells were immunoreactive for S-100. The melanin pigment was increased in the basal layer of the epidermis, suggestive of cafe-au-lait spots (Figure 3A-C).

Cytological examination of pleural fluid revealed atypical cells in small clusters showing marked degenerative changes.

The excised section was reddish-gray and had a wide area covered with hemorrhage and necrosis on the lung specimen. The histological examination demonstrated a tumor composed of malignant epithelial components admixed with mesenchymal component. The carcinomatous component was consistent with squamous cell carcinoma and adenocarcinoma. The sarcomatous component was characterized by interlacing fascicles or storiform growth pattern consisting of fusiform or spindle-shaped cells. The nuclei were more pleomorphic with numerous mitotic figures, and there were areas of necrosis and hemorrhage. Multinucleated giant cells of bizarre size and shape were seen (Figure 4, 5). No heterologous component such as bone, cartilage, or muscle was observed in the sarcomatous component. In immunohistochemical examination, all carcinomatous components were immunoreactive for pancytokeratin, cytokeratin 19 and epithelial membrane antigen (EMA). The sarcomatous component was positive for vimentin but not with pancytokeratin, cytokeratin 19, actin and EMA (Figure 6A-D). All other markers including desmin, cytokeratin $5 / 6$, thyroid transcriptional factor-1, and chromogranin were negative. On the basis of these findings, the patient was diagnosed to have a carcinosarcoma. Four months after the diagnosis, he died of systemic progression of tumor.

\section{DISCUSSION}

The NF-1 gene is located on the long arm of chromosome 17 which functions as a tumour supressor gene. It is a negative

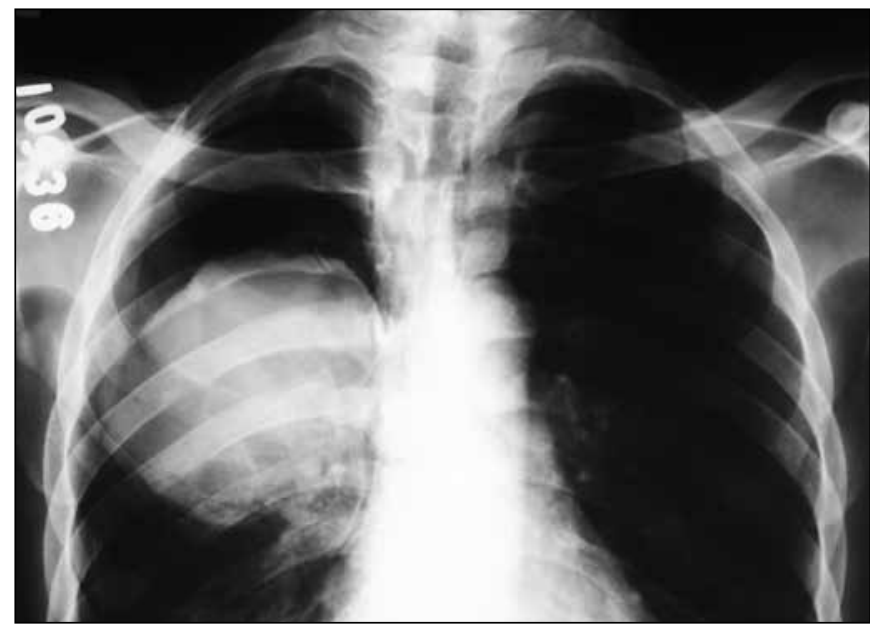

Figure 1: Chest roentgenogram showed a irregular homogeneus opacity in right middle and right upper zone.



Figure 2: $8 \times 8 \times 7 \mathrm{~cm}$ mass that have irregular border in right upper posterior and apical segment was seen on contrast enhanced chest computed tomography.

regulator of RAS oncogene. Mutation of NF-1 gene causes von Recklinghausen's disease. Its cardinal features are café-au-lait macules and multiple neurofibromas $(1,11)$. It is now known to be at least two clinically and genetically distinct diseases. The more common disease, formerly known as the peripheral form of neurofibromatosis, is designated NF-1. The less common disease, formerly known as the central form, is designated neurofibromatosis 2 (NF2)(bilateral vestibular schwannomas) (12). The risk of the cancer developing is four times greater than general population (13). Various cancers are known that occur in these patients including benign neurofibromas, intracranial gliomas, malignant peripheral nerve sheath tumors, malignant schwannoma, neurofibrosarcoma, rhabdomyosarcoma, juvenile chronic myelomonocytic 

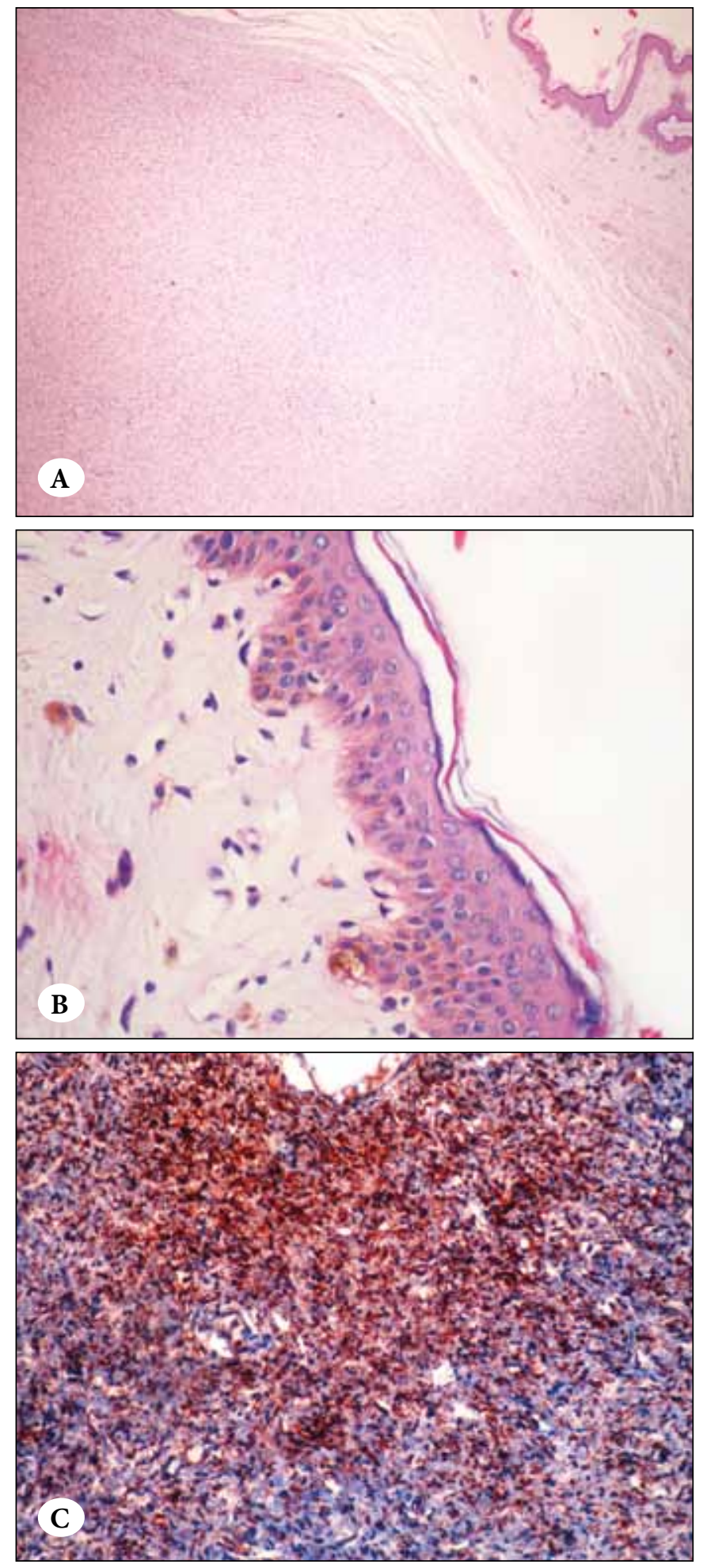

Figure 3: A) Neurofibroma with interlacing bundles of elongated cells in the subcutaneous region (H\&E, x40). B) Café-au-lait spots are characterized by an increase in melanin pigment in the basal layer of the epidermis (H\&E, x200). C) S-100 protein immunostaining of a neurofibroma (x100).

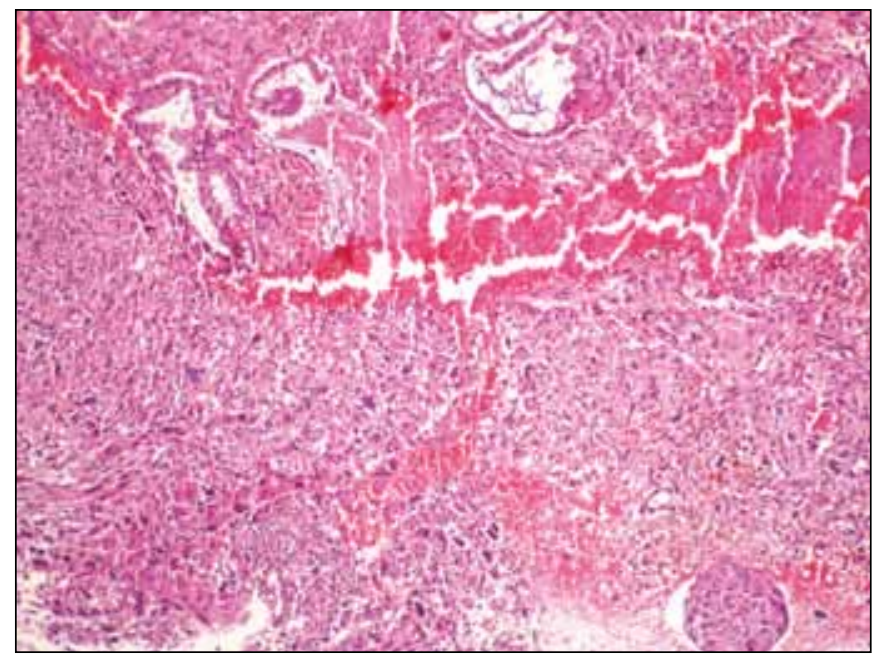

Figure 4: Mixed composition of carcinosarcoma; squamous cell carcinoma component, adenocarcinoma and sarcoma component (H\&E, $\mathrm{x} 40)$.

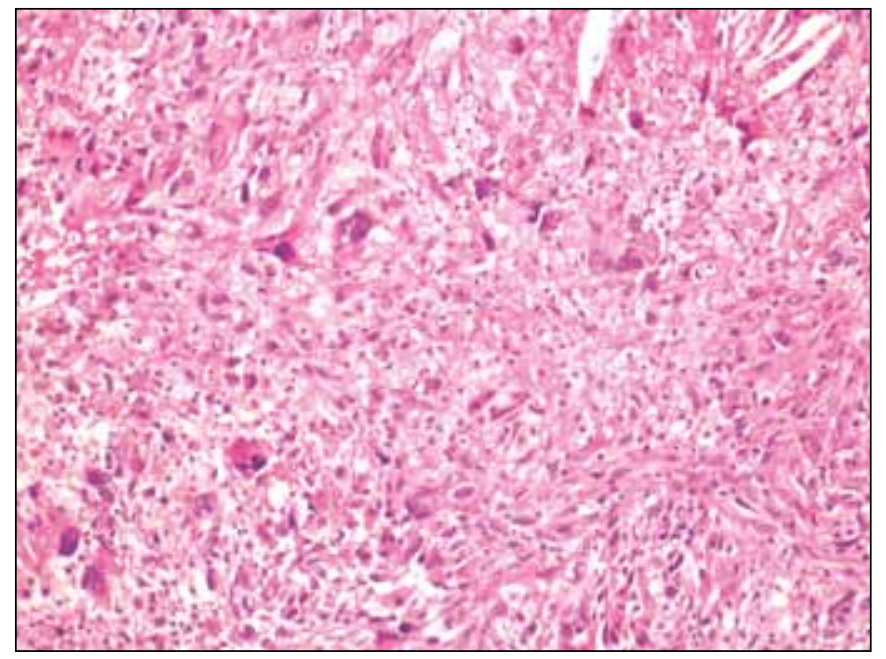

Figure 5: Sarcomatous component; multinucleated giant cells and pleomorphic bizarre nuclei (H\&E, x40).

leukemia, and pheochromocytoma $(2,14)$. Pulmonary involvement in NF-1 occurs in up to $20 \%$ of the case. The most common pulmonary manifestations are fibrosis and thin-walled bullae formation, predominantly in the upper zones $(11,15)$. However, the association of primary lung carcinoma with NF-1 is not common (\%2-5) (16).

The reported histological types of lung carcinoma are adenocarcinoma, squamous cell carcinoma, small cell carcinoma, large cell carcinoma, poorly differentiated carcinoma and metastatic lung carcinoma with neurofibromatosis (3-7,17). Japanese review reported only 11 cases of NF-1 with primary lung carcinoma until 1992. Adenocarcinoma was the most frequent histologic diagnosis $(72.9 \%)$ in this report as well as in most of the 

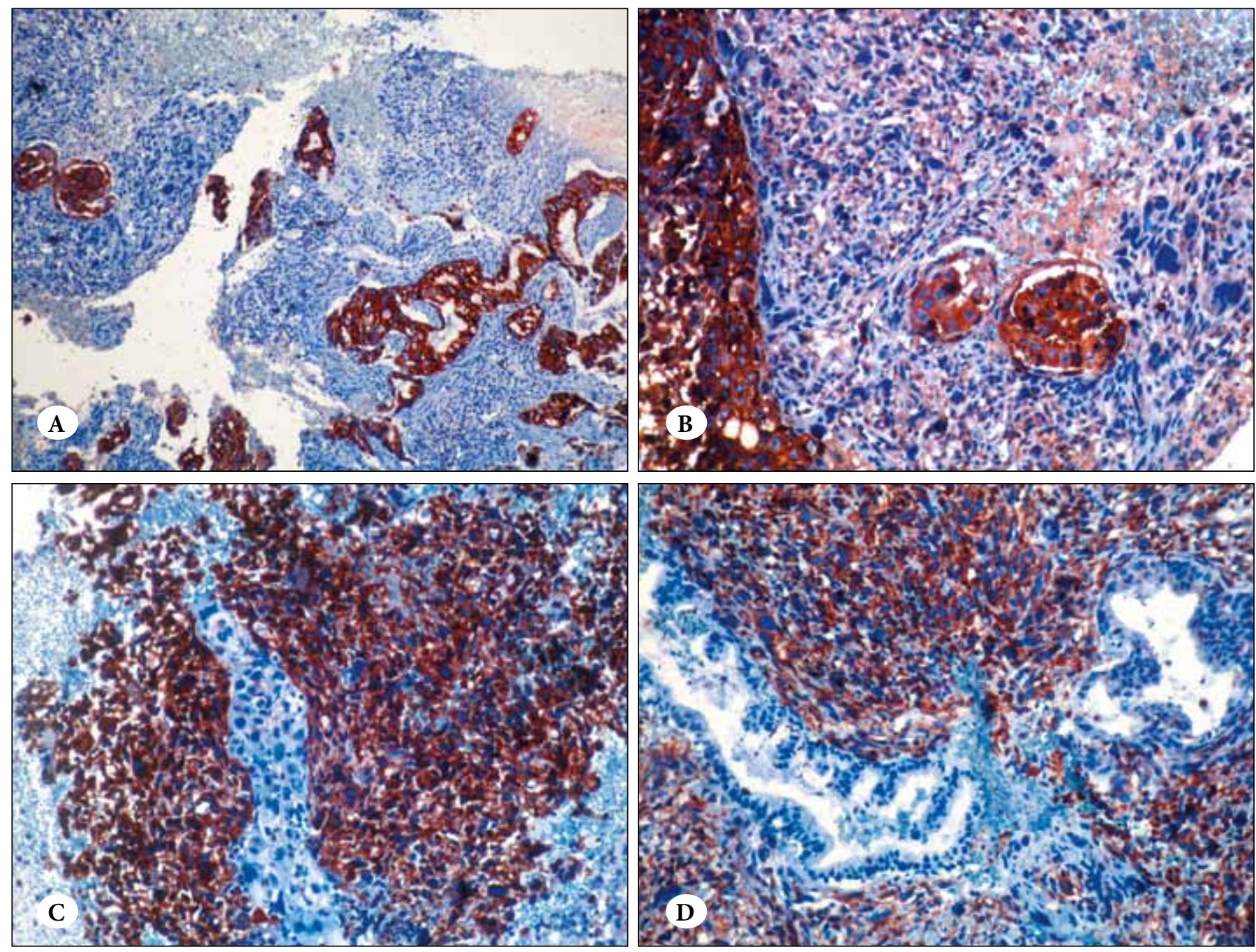

Figure 6: Carcinomatous component immunoreactive for A) pancytokeratin (x10) and B) epithelial membrane antigen (100x). The sarcomatous component stained with $\mathbf{C}$ ) vimentin, D) whereas not on carcinomatous component (x100).

recent surveys of lung cancer in Japanese population (7). Lung carcinosarcoma is a rare malignancy with a poor prognosis. It accounts for $0.2-0.27 \%$ of primary pulmonary malignancies (8).

As defined in the 2004 WHO criteria, there are five recognized subgroups representing a morphologic continuum: pleomorphic carcinoma, spindle cell carcinoma, giant cell carcinoma, carcinosarcoma, and pulmonary blastoma.

This variant is defined as a malignant tumour with a mixture of carcinoma and sarcoma containing differentiated sarcomatous elements. The carcinomatous component is most often squamous cell carcinoma (45-70\%), followed by adenocarcinoma (20-31\%), and large cell carcinoma (10\%). The malignant stroma often forms the bulk of carcinosarcomas, and only small foci of carcinoma may be seen (18). Koss et all reported that carcinosarcomas show a male-to-female ratio of 7.25:1, with a mean and median age of 65 years. They most often present as solitary masses in the upper lobes and average $7 \mathrm{~cm}$ in diameter. Most (62\%) were endobronchial or central tumors, whereas $38 \%$ were described as peripheral (19).

The most frequent symptoms were, chest pain, cough, hemoptysis, wheezing, dyspnea, fever and weight loss, in previous reports (20)

In several immunohistochemical examinations, the sarcomatous component was positive for vimentin, the carcinomatous component was positive for cytokeratin and EMA $(21,22)$.

In conclusion, carcinosarcoma is a rare tumor of the lung and association of carcinosarcoma with NF-1 is not common. 


\section{REFERENCES}

1. Hauser SL: Neurocutaneous Syndromes. In Fauci AS, Longo DL. (Eds): Harrison' Principles of Internal Medicine. 14th ed., New York, McGraw-Hill, 1998, 2404

2. Sakai A: Characterization of the neurofibromatosis type 1 gene and neurofibromin's role in cells. Nippon Rinsho 2000, 58: 1426-1429

3. Shimizu E, Shinohara T, Mor N, Yokota J, Tani K, Izumi K, Obashi A, Ogura T: Loss of heterozygosity on chromosome arm $17 \mathrm{p}$ in small cell lung carcinomas, but not in neurofibromas, in a patient with von Recklinghausen neurofibromatosis. Cancer 1993, 71:725-728

4. Shimizu E, Tsuchiya S, Watanabe S, Saitoh $R$ : Von Recklinghausen's disease with lung cancer derived from the wall of emphysematous bullae: case report. Intern Med 1994, 33 : 167-171

5. Gupta TB, Kumar V, Tandon S, Gill M: Primary carcinoma of the lung in von Recklinghousen neurofibromatosis: case report. Lung India 2009, 26:130-132

6. Gök M, Börüban C, Toy H, Kanat F, Kurt E, Uzun K: Akciğer kanseri ile nörofibromatosis birlikteliği. Tip Araştırmaları Dergisi 2006, 4:48-51

7. Dikensoy O, Tunçözgür B, Erbağcı Z, Filiz A: Primary adenocarcinoma of the lung in a case of von Recklinghausen neurofibromatosis. Turkish Journal of Cancer 2002, 3:32-36

8. Haraguchi S, Fukuda Y, Sugisaki Y, Yamanaka N: Pulmonary carcinosarcoma: immunohistochemical and ultrastructural studies. Pathol Int 1999, 49:903-908

9. Guarino M, Tricomi P, Giordano F, Cristofori E: Sarcomatoid carcinomas: pathological and histopathogenetic considerations. Pathology 1996, 28:298-305

10. Nakajima M, Kasai T, Hashimoto H, Iwata Y, Manabe H: Sarcomatoid carcinoma of the lung: a clinicopathologic study of 37 cases. Cancer 1999, 86:608-616

11. Dunn HG: Neurology. In Kelly WN. (Ed): Textbook of Internal Medicine. Philadelphia, Lippincott-Raven Publishers, 1997, 2398-2399
12. Weis SW,Goldblum JR: Benign tumors of peripheral nerves. In Goldblum JR, Weiss SW. (Eds): Enzinger and Weiss's Soft Tissue Tumors. 5th ed., Philadelphia, Mosby Elsevier, 2008, 835-837

13. Zöller ME, Rembeck B, Oden A, Samuelsson M, Angervall L: Malignant and benign tumors in patients with neurofibromatosis type 1 in a defined Swedish population. Cancer 1997, 79:2125

14. Sharif S, Moran A, Huson SM, Iddenden R, Shenton A, Howard E, Evans DG: Women with neurofibromatosis 1 are at a moderately increased risk of developing breast cancer and should be considered for early screening. J Med Genet 2007, 44: 481-484

15. Rossi SE, Erasmus JJ, McAdams HP, Donnelly LF: Thoracic manifestations of neurofibromatosis-1. AJR 1999, 173:1631-1638

16. Varadarajalu L, Khaneja S, Niazi M, Parithivel VS, Menon L, Fuentes GD: Adenocarcinoma masquerading as neurofibroma in a patient with von Recklinghausen's disease. Chest 2004,126: 927S-928S

17. Ozyardımcı N, Gozu RO, Ege E, Karadag M, Atak T, Yumrukcallı B: Solunum sistemi malignitesi ön tanisiyla tetkik edilen 2 nörofibromatozis olgusu. Bursa Devlet Hastanesi Tip Bülteni 1993, 9:25-32

18. Corrin B, Chang YL, Rossi G, Koss MN, Geisinger K, Wick MR, Nappi O, Finkelstein SD, Nakatani Y: Sarcomatoid Carcinoma. In Travis WD, Brambilla E, Müller-Hermelink HK, Haris CC. (Eds): Pathology \& Genetics Tumours of the Lung, Pleura, Thymus and Heart. Lyon, IARC Press, 2004, 53-58

19. Koss MN, Hochholzer L, Frommelt RA: Carcinosarcomas of the lung: a clinicopathologic study of 66 patients. Am J Surg Pathol 1999, 23:1514-1526

20. Davis MP, Eagen RT, Weiland LH, Pairolero PC: Carcinosarcoma of the lung: Mayo Clinic experience and response to chemotherapy. Mayo Clin Proc 1984, 59:598-603

21. Kefeli M, Yildiz L, Aydin O, Uzun O, Kandemir B: Sarcomatoid carcinomas of the lung: report of three cases. Turkish Journal of Pathology 2008, 24:64-68

22. Kim HM, Shin BS, Song YW, Lee SM, Jung SH, Kim CW, Kang KM, Jung IS, Na DJ: A case of pulmonary carcinosarcoma with persistent mild fever . Korean J Intern Med 2002, 17:78-82 